Ekonomiczne Problemy Usług nr 122

ISSN: 1896-382X | www.wnus.edu.pl/pl/edu/

DOl: 10.18276/epu.2016.122-10 | strony: 115-123

\title{
MALWINA POPIOEEK
}

Uniwersytet Jagielloński

\section{NIERÓWNOŚCI CYFROWE I PODZIAŁY CYFROWE DRUGIEGO RZĘDU JAKO WYZWANIE DLA GOSPODARKI OPARTEJ NA WEDZY}

\begin{abstract}
Streszczenie
Celem artykułu jest przybliżenie problemu nierówności i podziałów cyfrowych, a także ich znaczenia w procesach związanych z rozwojem struktur społeczeństwa informacyjnego i gospodarki opartej na wiedzy. W artykule dokonano przeglądu literatury pod kątem problematyki nierówności cyfrowych. Podjęta została także próba zdefiniowania pojęcia podziałów cyfrowych pierwszego, drugiego i trzeciego rzędu.

Słowa kluczowe: podziały cyfrowe, wykluczenie cyfrowe, podziały cyfrowe drugiego rzędu, podziały cyfrowe trzeciego rzędu, e-kompetencje.

\section{Wprowadzenie}

Intensywnie postępujący rozwój technologii komunikacyjno-informacyjnych (ICT) przyczynił się do radykalnych zmian obejmujących sferę społeczną, kulturową i ekonomiczną. Pojawienie się i upowszechnienie w społeczeństwie dostępu do ICT spowodowało gruntowne zmiany w sferze przepływu, wymiany i sposobów zarządzania informacją, która jest najważniejszym zasobem XXI wieku (Drucker 2000; Nierenberg 2011). Ten stan rzeczy powszechnie określa się mianem społeczeństwa informacyjnego. Mówiąc najprościej, społeczeństwo informacyjne można postrzegać jako produkt tzw. cywilizacji informatycznej (Muszyński 2006) wykazujący cechy charakterystyczne dla społeczeństwa trzeciej fali zdefiniowanego przez amerykańskiego futurologa A. Tofflera. Zgodnie z koncepcją tegoż autora w historycznym rozwoju cywilizacji można wyróżnić trzy następujące po sobie fale (agrarną, przemysłową i informacyjną). Każda z nich miała związek z wprowadzeniem nowej technologii (Toffler 1997).
\end{abstract}


Jak pisał Neil Postman: „Nowa technologia nic nie dodaje, ani niczego nie odejmuje. Nowa technologia wszystko zmienia” (Postman 1995, s. 28). W społeczeństwie informacyjnym obowiązują zatem zupełnie nowe zasady. Uwidacznia się to np. w sposobie funkcjonowania gospodarki. Mówi się zatem o gospodarce opartej na wiedzy, czy też e-gospodarce (Papińska-Kacperek 2008). Ogromne znaczenie ma przepływ informacji i rosnące wykorzystanie wiedzy. To właśnie wiedza, kształtowana w oparciu o informacje, staje się najważniejszym elementem gry rynkowej. Jak pisze G. Wronowska, gospodarka oparta na wiedzy „traktowana jest jako naturalna konsekwencja ewolucji systemu gospodarczego, przebiegająca pod wpływem pojawienia się epokowych innowacji, a nie jako zbiór powiązań istniejących w gospodarce niezależnie od funkcjonującego systemu gospodarczego. Gospodarka oparta na wiedzy nie jest sztuczną strukturą, ale naturalną konsekwencją rozwoju systemu gospodarczego" (Wronowska 2004).

Nowe zasady rządzące sferą społeczną, kulturalną i ekonomiczną generują jednakże nowe problemy społeczne. Jednym z największych wyzwań e-gospodarki jest nierównomierny rozwój jej struktur. Związane jest to często z kwestią podziałów społecznych, które w nowym typie społeczeństwa przybierają formę podziałów cyfrowych (digital divide). Analizowanie tego problemu jest niezwykle istotne, zarówno z badawczego, jak i pragmatycznego punktu widzenia.

\section{Nierówności w dostępie do technologii komunikacyjno-informacyjnych}

Pojawienie się Internetu i nowych mediów wzbudziło początkowo bardzo entuzjastyczne nastroje. Wielu autorów w upowszechnieniu dostępu do ICT dostrzegało remedium na wiele tradycyjnych problemów społecznych. Jak pisze M. Cebula: „Powstaniu globalnej sieci towarzyszyło nieco naiwne przekonanie, że stwarza ona niespotykane dotąd szanse na poprawę sytuacji życiowej wykluczonych czy upośledzonych społecznie grup, zmniejszenie nierówności i emancypację mniejszości, ponieważ umożliwi dotarcie do informacji, wiedzy i kontaktów w prosty i tani sposób. Praktyka życia społecznego szybko zweryfikowała ten pogląd i pokazała, że Internet jest nie tyle obszarem niwelowania różnic między ludźmi, ile raczej sferą reprodukowania już istniejących podziałów i dystansów(...)" (Cebula 2014, s. 255). Jak słusznie zauważają S. Czapnik i M. Kuś, entuzjastyczne nastroje wynikały przede wszystkim z przekonania, iż postęp technologiczny jest najwyższym osiągnięciem ludzkości i jedyną drogą do, traktowanego powszechnie jako aksjomat, rozwoju (Czapnik i Kuś 2010).

Jednakże już w latach dziewięćdziesiątych wielu badaczy sceptycznie odnosiło się do procesów mających na celu intensyfikację rozwoju i upowszechnienie ICT. T. Goban-Klas i P. Sienkiewicz dostrzegli zagrożenie w zróżnicowanym poziomie wiedzy i umiejętności użytkowników ICT. Zdaniem autorów korzystanie 
z nowych technologii jest wbrew pozorom dość skomplikowane, a zatem do efektywnego ich wykorzystywania niezbędne są pewne specyficzne umiejętności i kompetencje. Szybko zmieniające się środowisko nowych mediów pogłębia lukę informacyjną pomiędzy tymi, którzy potrafią, a tymi, który nie są w stanie nadążyć nad rozwojem technologii. Prowadzi to nieuchronnie do pewnego rodzaju „komputerowego analfabetyzmu” (Goban-Klas i Sienkiewicz 1999).

Nierówności cyfrowe początkowo rozpatrywano niemalże wyłącznie przez pryzmat wykluczenia cyfrowego, a więc z perspektywy dostępu albo braku dostępu do komputerów i Internetu (van Dijk 2010). Okazało się jednak, że kwestia wykorzystywania ICT ma charakter bardziej złożony i wielowymiarowy, a sam dostęp do ICT nie jest w żadnym razie równoznaczny z efektywnym ich użytkowaniem. Wielu badaczy zaczęło dostrzegać wielowymiarowość tego problemu i definiować różne poziomy dostępu do technologii. J. van Dijk wyróżnił 4 poziomy dostępu do ICT:

- dostęp motywacyjny - pierwszy poziom dostępu, związany z odczuwaniem bądź nieodczuwaniem potrzeby korzystania z ICT;

- dostęp materialny (fizyczny) - drugi poziom, w którym osoba odczuwająca potrzebę korzystania posiada bądź nie posiada dostępu fizycznego do odpowiedniego sprzętu;

- dostęp kompetencyjny - na tym poziomie uwidacznia się zróżnicowanie osób korzystających z ICT pod kątem ich e-umiejętności i e-kompetencji niezbędnych do praktycznego użytkowania technologii w codziennym życiu;

- dostęp użytkowy - związany z częstotliwością i efektywnością użytkowania ICT (van Dijk 2010).

Nieco zmodyfikowaną klasyfikację wykluczenia proponuje D. Bednarczyk. Jej zdaniem można mówić o trzech stopniach cyfrowego wykluczenia: pierwszy związany jest $\mathrm{z}$ dostępem materialnym, drugi to dostęp kompetencyjny, natomiast trzeci dotyczy motywacji do faktycznego korzystania z nowych mediów (Bednarczyk 2014).

Początkowo sądzono, że powszechna komputeryzacja i informatyzacja będzie skutecznie przeciwdziałać nierównościom cyfrowym. W Polsce poziom wykluczenia cyfrowego maleje systematycznie z roku na rok, na co wskazują reprezentatywne dla całej populacji badania przeprowadzane w ramach Diagnozy Społecznej. Z badań tych wynika, że dostęp do komputera i Internetu posiada już ponad 70\% polskich gospodarstw domowych (Batorski 2015). Jak jednak pisze D. Bednarczyk: „Dostęp fizyczny, oznaczający fizyczną możliwość korzystania z komputera, Internetu, nowych mediów, wydawał się w pierwszej fazie diagnozowania cyfrowego wykluczenia najważniejszym, a nawet wystarczającym elementem rozwoju nowoczesnego, cyfrowego społeczeństwa. Okazało się jednak, że owszem, jest to konieczny element cyfrowego włączania, ale niewystarczający do przezwyciężenia nierówności cyfrowych i związanych z nimi nierówności społecznych” (Bednarczyk 2014). Okazało 
się zatem, że problem cyfrowych nierówności jest bardzo wielowymiarowy, a podchodzenie do e-integracji wyłącznie z perspektywy eliminowania zjawiska cyfrowego wykluczenia obecnie okazuje się być niewystarczające.

\section{Podziały cyfrowe w społeczeństwie informacyjnym}

Malejący odsetek osób pozbawionych dostępu do ICT nie przyczynił się do eliminacji problemu nierównomiernego rozwoju struktur społeczeństwa informacyjnego. Wydaje się, że problem ten znacznie lepiej zrozumieć patrząc na niego przez pryzmat tzw. podziałów i nierówności cyfrowych, które to podejście traktuje nierówności cyfrowe bardziej kompleksowo. W literaturze definiuje się dwa główne typy podziałów: pierwszego i drugiego rzędu.

\section{Podziały pierwszego i drugiego rzędu}

Podziały cyfrowe pierwszego rzędu (first level digital divide) związane są z fizycznym dostępem do technologii, a więc korespondują z pojęciem wykluczenia cyfrowego. O podziałach cyfrowych drugiego rzędu (second level digital divide) mówi się natomiast $\mathrm{w}$ kontekście zróżnicowania e-umiejętności poszczególnych jednostek, co generuje nierówności wśród osób aktywnie korzystających z Internetu. Zdaniem badaczki tego zagadnienia, E. Hargittai, kwestią kluczową nie jest sam dostęp do sieci, a raczej umiejętne jej wykorzystanie. Hargittai i DiMaggio wyróżniają więc pięć wymiarów podziałów cyfrowych:

- w znaczeniu możliwości technicznych (technical means) - dostęp do odpowiedniego sprzętu, oprogramowania, jakość dostępu do sieci, np. szybkość połączenia;

- w znaczeniu jakości użytkowania (location of access) - miejsce dostępu (praca, dom), swoboda korzystania;

- w kwestii wzorców użytkowania (use patterns) - np. wiedza o sposobach wyszukiwania informacji, przyzwyczajenia związane $\mathrm{z}$ korzystaniem z sieci;

- w kwestii korzystania z sieci relacji społecznych (social support networks) - możliwość korzystania z kapitału sieci społecznych;

- w kwestii umiejętności (skill) - umiejętność dokonania krytycznej oceny, np. w odniesieniu do wiarygodności pozyskiwanych informacji.

Podziały cyfrowe drugiego rzędu odnoszą się zatem do różnic w zakresie wiedzy i umiejętności internautów i konsekwencji za tym idących. Będzie to więc np. różnica w wykorzystaniu narzędzi tzw. Web $2.0^{1}$. O ile zatem w przypadku

1 Pojęcie Web 2.0 kładzie nacisk na architekturę stron internetowych, która pozwala nie tylko odbierać treści, ale także je współtworzyć. 
podziałów pierwszego rzędu ludzie nie korzystają z Internetu, o tyle w drugim przypadku korzystający będą wyłącznie konsumować treści internetowe, nie posiadając wystarczających umiejętności, aby owe treści tworzyć, czy nawet krytycznie je oceniać. W tabeli 1 zamieszczone zostało porównawcze zestawienie first i second level digital divide, $\mathrm{z}$ uwzględnieniem takich czynników, jak rodzaj dostępu, charakter barier, sposoby przeciwdziałania i konsekwencje występowania.

Tabela 1

Różnice pomiędzy podziałami cyfrowymi pierwszego i drugiego rzędu

\begin{tabular}{|l|l|l|}
\cline { 2 - 3 } \multicolumn{1}{c|}{} & \multicolumn{1}{c|}{$\begin{array}{c}\text { Podziały cyfrowe pierwszego } \\
\text { rzędu (first level digital divide) }\end{array}$} & $\begin{array}{c}\text { Podziały cyfrowe drugiego rzędu } \\
\text { (second level digital divide) }\end{array}$ \\
\hline $\begin{array}{l}\text { Charakter } \\
\text { barier }\end{array}$ & $\begin{array}{l}\text { Twarde: infrastrukturalne, np. } \\
\text { brak dostępu do komputera } \\
\text { i Internetu, słaba jakość łącza, } \\
\text { itp. }\end{array}$ & $\begin{array}{l}\text { Miękkie: np. kompetencyjne, psycho- } \\
\text { logiczne, motywacyjne, związane } \\
\text { z wiedzą, świadomością zagrożeń, } \\
\text { umiejętnościami krytycznej oceny } \\
\text { treści, itp. }\end{array}$ \\
\hline Rodzaj dostępu: & Fizyczny, techniczny & Kompetencyjny \\
Czynniki deter- & $\begin{array}{l}\text { O charakterze socjo- } \\
\text { ekonomicznym, np. zbyt niskie } \\
\text { dochody lub niepełnosprawność } \\
\text { uniemożliwiająca korzystanie } \\
\text { z ICT }\end{array}$ & $\begin{array}{l}\text { O charakterze socjo- } \\
\text { demograficznym, np. wiek, wy- } \\
\text { kształcenie, poziom życia, poziom } \\
\text { świadomości }\end{array}$ \\
\hline $\begin{array}{l}\text { Sposób przeciw- } \\
\text { działania }\end{array}$ & Komputeryzacja, informatyzacja & Odpowiednia edukacja medialna \\
\hline Konsekwencje & Wykluczenie cyfrowe & $\begin{array}{l}\text { Nierówności w dostępie do informa- } \\
\text { cji, zagrożenie utratą prywatności, } \\
\text { zagrożenie cyberprzestępczością }\end{array}$ \\
\hline
\end{tabular}

Źródło: opracowanie własne.

W literaturze pojawia się także pojęcie podziałów cyfrowych trzeciego rzędu (third level digital divide). Ten typ nierówności cyfrowych jest jednak różnie definiowany i na razie brak wśród badaczy zgodności co do tego, co należałoby pod tym pojęciem rozumieć. Angielska politolog P. Norris podziały trzeciego rzędu definiuje jako tzw. democratic divide, a więc kwestie związane $\mathrm{z}$ e-partycypacją i rolą ICT w procesach polegających na tworzeniu społeczeństwa obywatelskiego (Norris 2001). Z kolei technosocjolog Z. Tufekci źródeł podziałów cyfrowych trzeciego rzędu dopatruje się pośród różnic w przyzwyczajeniach i sposobach korzystania z sieci relacji społecznych, np. za pośrednictwem serwisów społecznościowych (Tufekci 2011). Pracujący na Uniwersytecie SWPS K. Henne, pod pojęciem third level digital divide rozumie natomiast odmienne wzorce korzystania z ICT, które 
mogą sprzyjać dalszemu rozwojowi jednostek, bądź też przeciwnie - hamować ów rozwój (Henne 2009).

Tabela 2

Różne podejścia do podziałów cyfrowych trzeciego rzędu

\begin{tabular}{|c|c|c|c|}
\hline & P. Norris & Z. Tufekci & K. Henne \\
\hline 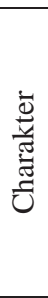 & $\begin{array}{l}\text { Poziom zaangażowania poli- } \\
\text { tycznego za pośrednictwem } \\
\text { ICT, e-partycypacja politycz- } \\
\text { na i tworzenie społeczeństwa } \\
\text { obywatelskiego (tzw. demo- } \\
\text { cratic divide) }\end{array}$ & $\begin{array}{l}\text { Różnice w korzystaniu } \\
\text { z platform społeczno- } \\
\text { ściowych, np. Facebooka. } \\
\text { Różnice i nierówności } \\
\text { dotyczące wykorzystania } \\
\text { potencjału tkwiącego } \\
\text { w sieci relacji społecz- } \\
\text { nych }\end{array}$ & $\begin{array}{l}\text { Wzorce korzystania } \\
\text { z ICT, które mają bezpo- } \\
\text { średni wpływ na rozwój } \\
\text { jednostek. Nierówności } \\
\text { w zakresie szans i możli- } \\
\text { wości rozwoju uzyskiwa- } \\
\text { nych dzięki efektywnemu } \\
\text { wykorzystaniu ICT }\end{array}$ \\
\hline 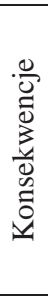 & $\begin{array}{l}\text { Nierówności w zakresie } \\
\text { e-partycypacji politycznej, } \\
\text { nierówny udział w tworzeniu } \\
\text { e-demokracji }\end{array}$ & $\begin{array}{l}\text { Różnice w wykorzystaniu } \\
\text { możliwości i potencjału } \\
\text { tkwiącego w sieciach } \\
\text { relacji społecznych, moż- } \\
\text { liwość bycia wykluczo- } \\
\text { nym z różnych form } \\
\text { aktywności społecznej }\end{array}$ & $\begin{array}{l}\text { Tzw. efekt Mateusza } \\
\text { (posiadający wiedzę } \\
\text { i umiejętności, lepiej } \\
\text { sytuowani, polepszają } \\
\text { swoją sytuację, zwiększa } \\
\text { się luka pomiędzy nimi } \\
\text { a osobami mniej efektyw- } \\
\text { nie korzystającymi z ICT) }\end{array}$ \\
\hline
\end{tabular}

Źródło: opracowanie własne (na podst. Norris 2001; Tufekci 2011; Henne 2009).

Wydaje się jednak, że podziały cyfrowe trzeciego rzędu są pochodną podziałów drugiego rzędu, a ich istoty należy dopatrywać się we wpływie ICT na dalsze reprodukowanie różnic pomiędzy jednostkami. Być może lepszym rozwiązaniem byłoby wyróżnienie poszczególnych segmentów czy przejawów podziałów drugiego rzędu aniżeli wyodrębnianie kolejnego poziomu nierówności. Można powiedzieć, iż przy nierównościach wtórnych, a więc nie związanych z barierami twardymi, szczególnie istotne są następujące kwestie:

- cyberbezpieczeństwo - np. umiejętne zarządzanie prywatnością, świadomość dotycząca cyberprzestępczości i umiejętność ochrony przed tego typu zagrożeniami;

- indywidualne zarządzanie informacją - np. dobór odpowiednich narzędzi, które umożliwią szybkie i skuteczne, (a przy tym bezpieczne) zarządzanie zarówno w zakresie pozyskiwania, jak i nadawania treści i informacji;

- zarządzanie swoim wizerunkiem w sieci (do celów prywatnych, a także marketingowych; Polańska 2013) - umiejętne zarządzanie swoim wizerunkiem, np. za pośrednictwem serwisów społecznościowych; zarządzanie bezpieczne i skuteczne, np. efektywne wykorzystywanie możliwości, jakie dają sieci powiązań społecznych. 


\section{Podsumowanie}

W dobie intensywnego rozwoju e-gospodarki korzystanie z ICT przestało być wyborem, a stało się koniecznością. Osoby nie mające dostępu do nowoczesnych technologii, nie potrafiące efektywnie z nich korzystać są zagrożone różnymi formami marginalizacji. Badacze zauważają często, że podziały cyfrowe są pochodną tradycyjnych podziałów socjoekonomicznych (Sarama 2004; Batorski 2015; Henne 2009). Przeciwdziałanie nierównościom leżeć powinno zatem nie tylko w gestii samych obywateli, ale także i państw. Jak pisze M. Sarama: „W społeczeństwie informacyjnym dostęp do zasobów informacyjnych i komunikacyjnych jest kluczowy dla rozwoju społecznego i gospodarczego. Dlatego też bardzo ważne jest podejmowanie działań ukierunkowanych na zmniejszenie luki cyfrowej”. Istotna jest zatem odpowiednio skoordynowana polityka e-integracyjna wsparta systematycznie prowadzonymi badaniami (Budziewicz-Guźlecka 2014).

Podziały cyfrowe drugiego rzędu stają się obecnie jednym z największych wyzwań w tworzeniu struktur społeczeństwa informacyjnego i gospodarki opartej na wiedzy. Brak odpowiednich rozwiązań w tym zakresie może skutkować stałym pogłębianiem się luki cyfrowej, hamować rozwój takich sektorów, jak e-administracja czy e-biznes (zob. Czaplewski 2007), a także wpływać niekorzystnie na rozwój w obszarze e-edukacji czy e-demokracji (zob. Norris). Konieczna wydaje się zatem pogłębiona analiza tego zagadnienia, uwzględniająca w szczególności przyczyny podziałów o charakterze wtórnym, mająca jednak także na celu wypracowanie rozwiązań o charakterze pragmatycznym, pozwalających na zmniejszanie luki informacyjnej i przeciwdziałanie podziałom już istniejącym.

\section{Literatura}

1. Batorski D. (2015), Technologie i media $w$ domach $i$ w życiu Polaków, w: Raport: Diagnoza społeczna 2015, red. J. Czapiński, T. Panek, Rada Monitoringu Społecznego, Warszawa.

2. Bednarczyk D. (2014), Przeciwdziałanie cyfrowemu wykluczeniu (e-integracja) $w$ Polsce, Biuletyn EBIB [online], nr 9 (154), Gromadzenie i zabezpieczanie danych cyfrowych.

3. Budziewicz-Guźlecka A. (2014), Rola działalności naukowo-badawczej w rozwoju gospodarki opartej na wiedzy, Zeszyty Naukowe Uniwersytetu Szczecińskiego nr 808, Ekonomiczne Problemy Usług nr 112.

4. Cebula M. (2014), Społeczne zróżnicowanie umiejętności informatycznych, „Ruch Prawniczy, Ekonomiczny i Socjologiczny”, nr 1.

5. Czaplewski M. (2007), E-biznes jako kierunek doskonalenia ustug ubezpieczeń gospodarczych, PTE, Szczecin. 
6. Czapnik S., Kuś M. (2010), Nowy wspaniały świat, Mity cyberprzestrzeni a rzeczywistość, w: Com.unikowanie $w$ zmieniajacym się społeczeństwie, red. M. Niezgoda, M. Świątkiewicz-Mośny, A. Wagner, Kraków.

7. Dijk J. van (2010), Społeczne aspekty nowych mediów, PWN, Warszawa.

8. Drucker P. (2000), Zarzadzanie w XXI wieku, Muza, Warszawa.

9. Goban-Klas T., Sienkiewicz P. (1999), Społeczeństwo informacyjne: szanse, zagrożenia, wyzwania, Wydawnictwo Postępu Telekomunikacji, Kraków.

10. Hargittai E., Second-Level Digital Divide: Differences in People's online skills, http://journals.uic.edu/ojs/index.php/fm/article/view/942/864 [dostęp 1.02.2016].

11. Henne K. (2009), Zmierzamy ku trzeciemu już poziomowi cyfrowego podziału, w: Raport „Portret internauty” [online], https://marketingowe.files.wordpress.com/ 2015/06/portret-internauty.pdf [dostęp 1.02.2016].

12. Muszyński J. (2006), Społeczeństwo informacyjne - szkice politologiczne, Wyd. A. Marszałek, Toruń.

13. Nierenberg B. (2011), Zarządzanie mediami - ujęcie systemowe, Wyd. UJ, Kraków.

14. Norris P. (2001), Digital Divide: Civic Engagement, Information Poverty, and the Internet Worldwide, Cambridge University Press.

15. Papińska-Kacperek J. (2008), Społeczeństwo informacyjne, PWN, Warszawa.

16. Polańska K. (2013), Kreatywność w nowej gospodarce - perspektywa społecznościowa, Zeszyty Naukowe Uniwersytetu Szczecińskiego nr 809 „Ekonomiczne Problemy Usług” nr 113, s. 313-321.

17. Postman N. (1995), Technopol, PIW, Warszawa.

18. Sarama M. (2004), Podział cyfrowy - nierówności w społeczeństwie informacyjnym, w: Nierówności społeczne a wzrost gospodarczy. Polityka społecznoekonomiczna, z. 4, Wydawnictwo Uniwersytetu Rzeszowskiego, Rzeszów.

19. Toffler A., Trzecia Fala, PIW, Warszawa 1997.

20. Tufekci Z. (2011), Cyberasociality and the Online Sociality Divide: Third Level Digital Divide?, [online], http://technosociology.org/wp-content/uploads/2012/04/ cyberasocial-zeynep-asa-2011.pdf [dostęp 1.02.2016].

21. Wronowska G. (2004), Gospodarka oparta na wiedzy jako etap ewolucji współczesnej gospodarki, w: Unifikacja gospodarek europejskich: szanse i zagrożenia, red. A. Manikowski, A. Psyk, WWZ, Warszawa. 


\title{
FIRST AND SECOND LEVEL DIGITAL DIVIDE AS A CHALLENGE FOR
} THE INFORMATION SOCIETY AND KNOWLEDGE BASED ECONOMY

\begin{abstract}
Summary
The paper presents problem of digital inequalities and digital divide. It focuses especially on the first, second and third level digital divide. The article reviews selected authors views on the digital inequality and describes different approaches to this issue. Keywords: first level digital divide, second level digital divide, third level digital divide.
\end{abstract}

Translated by Malwina Popiołek 
